\title{
Stereotype of Racial issue on \#starterpack
}

\author{
Hakeemi Harris Ayedoji \\ School of Literature, Language and Media \\ University of The Witwatersrand \\ South Africa \\ hakeemi@gmail.com
}

Citation: Ayedoji, H. H. (2021). Stereotype of racial issue on \#starterpack. Notion: Journal of Linguistics, Literature, and Culture Vol 3(1), p. 44-52. http:// doi.org/notion.v3i1.3926

\begin{tabular}{l|l}
\multicolumn{1}{c}{ Article Info } & \multicolumn{1}{c}{ ABSTRACT } \\
\hline Article History & $\begin{array}{l}\text { Semiotic comes from the Greek word, which is semeion (sign). Nevertheless, } \\
\text { generally, semiotics is a study which concerns about the existence of sign in society. } \\
\text { - Article Received } \\
\text { We could find signs everywhere in the form of words, images, and also objects. } \\
4^{\text {th }} \text { April } 2021\end{array}$ \\
$\begin{array}{l}\text { - Article Accepted } \\
22^{\text {nd }} \text { April } 2021\end{array}$ & $\begin{array}{l}\text { According to Pierce's study, something could be categorized into signs if it could be } \\
\text { \#starterpack tweets on Twitter. The data used is focused on the \#starterpack tweets } \\
\text { with white and black people context. To collect the data, the researcher used the } \\
\text { observation method and used note technique. From the analysis, the researcher } \\
\text { \#starterpack tweets with mainly four images in them. All the data are analyzed with }\end{array}$ \\
Keywords & $\begin{array}{l}\text { the triadic signs, which are signs, objects, and interpretations. The signs analyzed } \\
\text { show objects and interpretations that lead to the gap between white and black } \\
\text { Signs }\end{array}$ \\
$\begin{array}{l}\text { Tweets } \\
\text { Stereotype }\end{array}$ & $\begin{array}{l}\text { people. Those gaps then lead to stereotypes of white and black people. } \\
\text { Black and White }\end{array}$
\end{tabular}




\section{INTRODUCTION}

A simple idea of communicating made by Jack Dorsey, Ev Williams, Biz Stone, and Noah Glass in 2006 turns Twitter into a well-known social media nowadays. After much improvisation, ten years later, it is impossible to say that the Z Generation does not know about this social media, which it is bluebird icon can recognize. A significant number of users who enjoy Twitter make Twitter regularly increase their profit through the investment in the advertisement. Using a text message on the user's profile to share content is the way Twitter works. In a day, according to twitter.com, 280 characters, including the hashtag, are allowed to be shared by Twitter's users. What is a hashtag? A Hashtag is a relevant word or phrase represented by the "\#" symbol on Twitter. Hashtag contains essential information that could help people to follow the related topic. By typing a word or some words after the sign \# on the Twitter searching bar, people could see and join the conversation about the related topic on the hashtag[11]. On the other hand, people could also follow the conversation around the hashtag by clicking the word/words with the hashtag on it.

If there is a hashtag, there will be trending[1][2]. A trending topic is topics discussed by Twitter users more than the others across the world and being put in the Trending Topic bar. In every second, what people are talking about on Twitter is constantly being identified. By identifying the tweets, Twitter could determine topics frequently discussed at a particular time, thus why the topics that become trending are constantly changing every hour. One of the trending that became everyone's attention since early 2000 is the Starter Pack trending. According to the Urban Dictionaries, Starter Pack means some objects, characteristics, or actions that make up a particular person.

Meanwhile, on Twitter, four photos were posted simultaneously representing a particular person called the Starter Pack. At the very first, the Starter Pack became trending on Twitter only in the United States. However, people, not only the westerners, including me, find this trending is interesting. I try to go deep into this Starter Pack hashtag. After I researched the Starter Pack hashtag, it turns out there are various starter pack tweets with a different kind of context. The context in a starter pack tweet could be intended to be sarcasm or a joke[4]. It surprises me that some starter pack tweets could be very offensive to a particular race. I found that many starter pack tweets used sensitive content about white and black people. Those tweets somehow look like describing some particular races. Moreover, day by day, starter pack tweets that use white and black people context always increase. Therefore, my interest in this case raises.

These sensitive tweets are sent mainly by white people in the United States. However, not only white people but some black people sent this kind of tweet too[14]. People usually consider these tweets as jokes which also wildly inappropriate. Meanwhile, these kinds of tweets become everyday things in the United States timeline. This phenomenon should pop up a huge question mark in our head. Why can people not or do not realize it as an appropriate and offensive thing?[15] What will happen if people keep taking these tweets as jokes?[16]

Jha, Raj, \& Gangwar[9] say that women's and men's images on the magazine could reflect them differently. In some cases, the images in the magazine could reflect women as powerless individuals. Meanwhile, men could be reflected as influential individuals. Second, this thesis would be related to one research from The Opportunity Agenda titled Media Representation and Impact on the Lives of Black Men and Boys. This research focuses on how media and communications could represent and affect black men and boys in American society in many areas. This research simply about how media could easily create a new version of men and women through the images on the advertisement according to Chandler[3], Cobley \& Jansz[5] emphasize that images on the media have the most significant impact on viewers' negative points of view and expectations of black men and boys. In short, public perceptions and attitudes toward black males affected by the images on the media could make a particular situation on black men and boys seem natural or inevitable[6][12].

Kulaszewicz's[10] view on racism in media explores how media contributes to stigma, leading to stereotyping and racism in straightforward ways. 
Kulaszewicz says that stereotyping could occur in individuals in society, including people who make the media content. The person who has already been affected by racial tension and misperception could produce media content that includes stereotypes in a negative way. During the beginning era of media, African Americans could not represent their true identities because the white people who owned the media controlled what images to portray black people. This study examines the images presented to the viewers and how those images could affect the viewer's emotions and behaviors toward black people.

Meanwhile, this study will talk about how some tweets with simple pictures could have a deep meaning and effect. These pictures could reflect the gap between white and black people then affects people's view of both parties. In this study, the researcher will find how people could interpret the pictures of white or black people in one tweet. According to those tweets, the researcher will interpret and explain people's views and perceptions of black people nowadays. Then, I will try to expose the factors in those tweets which could indicate stereotyping. I will use the theory of semiotics by Charles Sanders Pierce to analyze and elaborate people's interpretation of their tweets to the black people.

\section{Semiotics}

The simplest definition of semiotics is the study of a sign. Historically, semiotics comes from the Greek word, which is semeion (sign). This Greek word "semesion" has a meaning sign[13]. However, generally, semiotics is a study which concerns about the existence of sign in society. The object of semiotics is everything that could be identified assign. However, semiotics studies more than visual things. In semiotics, we study wider than just symbolism in things. Semiotics has a relation with philosophy and linguistic. However, the broader link between semiotics and philosophy is on the language. This domain mainly taught about the meaning and reference between language, thought, and world. Furthermore, semiotics also has a relationship with one philosophical branch that is aesthetic or art.
One of the very broadest definitions of semiotics is from Umberto Eco. Umberto Eco emphasizes that "semiotics is concern with everything that can be taken as sign"[8]. Meanwhile, later, Ferdinand D. Saussure, born in Geneva, defines semiotics more specifically as "the science that studies the life of signs within society; it would be a part of social psychology and general psychology." After that, the two primary theories of semiotics were developed by Ferdinand de Saussure and an American philosopher, Charles Sanders Pierce. Both of them concern about semiotics as their subject and wrote a book about it[3]. The first edition of Ferdinand D. Saussure's course in General Linguistics mentioned that: Semiotics would investigate the nature of signs and the laws governing them. Linguistics is only one branch of this general science. The laws that semiology will discover will be laws applicable in linguistics, and linguistics will thus be assigned to a clearly defined place in the field of human knowledge. (p. 3) Saussure thought of semiotics as the branch of general science. "To the Saussurean semiotician, what matters most are the underlying structures and rules of semiotic system as a whole rather than specific performances or practices which are merely instances of its use" (p. 9).

Meanwhile, Pierce thought of semiotics as the formal doctrine of the sign. Pierce was working independently from Saussure, Peirce borrowed Locke's idea declaring that: Logic, in its general sense, is ... only another name for semiotic (sémeiötiké), the quasi necessary, or formal, the doctrine of signs. By describing the doctrine as 'quasinecessary,' or formal, I mean that we observe the characters of such signs as we know, and ... by a process which I will not object to naming abstraction, we are led to statements, eminently fallible, and therefore in one sense by no means necessary, as to what must be the characters of all signs used by a 'scientific' intelligence, that is to say, by an intelligence capable of learning by experience. (p. 3)

The sign is the heart of semiotics[5][7][12]. People who study sign called by semiotician. The importance of signs has been recognized throughout the history of philosophy and psychology as well. The theory of sign has an ever-lasting effect in the field of 
philosophy. We could find signs everywhere, from the form of words, images, sounds, actions, and objects. The meaning and definition of the sign have a vital role in semiotics. Umberto Eco, in his book, has argued that "the sign theory is implicit in perhaps all major thinkers' work" [8]

According to what is trending on Twitter, the hashtag "starter pack" term consists of four posting photos representing everything needed to be a certain kind of person or group. In \#starterpack, the jokes are usually stereotyping about trends, personal identity, group, or even race. Meanwhile, according to Urban Dictionary, a starter pack is the new sensation that hits social media. Usually, \#starterpack is created by teenagers and looked at by them too. The other definition of \#starterpack is a meme where people make collage photos meant to indicate the kind of person who likes those things. The vice also made an article about this trending; \#starterpack. It says that since 2014, social media are loaded with starter packs, and most of them are sadly accurate. The topic in \#starterpack usually about stereotyping people. There are many starter packs, such as the social segment starter pack and social statuses starter pack. Some of the most popular starter packs are racist. Why? Because it addresses ethnicity, nationality, and religion in a wrong way.

\section{METHODOLOGY}

In order to achieve the aims of this research, some methods are used to help analyze and examine it, such as sources of the data, method of analyzing data, and method of collecting data. Overall, the method used to do the research is the descriptive qualitative method that focuses on semiotic and stereotypes. It means this research will provide argumentation, add evidence from pictures, and relate it with the various theory or journals about stereotypes.

The primary data is analyzed based on the words and pictures on the \#starterpack tweets and the replies from those tweets. Thus, the source of the data is the secondary data from \#starterpack tweets on Twitter. Meanwhile, the secondary data in this research are from the photos on the tweets, journals, and papers related to this research topic.
In collecting the data, the researcher first searches all tweets that have a starter pack on them between 2019 and 2020. Then, the researcher filters and chooses the tweets that only contain white and black people as the topic. Next, the researcher chooses the tweets with related words or replies. Not only focuses on choosing the words and replies, but the researcher also downloads some journals and papers which reliable and relevant to the stereotypes study.

In this study, first, the researcher analyzes the words or sentences on the \#starterpack tweets using the semiotic approach. The researcher chooses the semiotics theory by Charles Sanders Pierce to analyze the tweets and the pictures attached to those tweets. After that, the researcher relates the interpretation of the words and pictures on those tweets with journals, news, and relevant videos. Finally, the researcher constructs the result of those analyzing into words using the qualitative method.

\section{RESULT AND DISCUSSION}

Charles Sanders Pierce defined a sign as "something which stands to somebody for something." Furthermore, Pierce divided signs into three main types: sign, object, and interpretant (EP2, 478). Besides that, the theory of factors stereotypes by Aboud \& Doyle, 1996. Aboud \& Doyle stated that we learn our stereotypes in part through our communications with parents and peers. Also, according to (Brown, 1995) we learn stereotypes from the behaviors we see portrayed in the media. Based on the three main types of signs by Charles Sanders Pierce, the researcher could find 36 \#starterpack tweets relevant to that theory. The data consist of a sign, an object, and an interpretant. In the data, the researcher found a sign, object, and interpretant on 20 \#starterpack tweets with white people context. However, the researcher also found the sign, object, and interpretant on 20 \#starterpack tweets, which has black people context. The result of three main types of signs can be seen from the table below: 


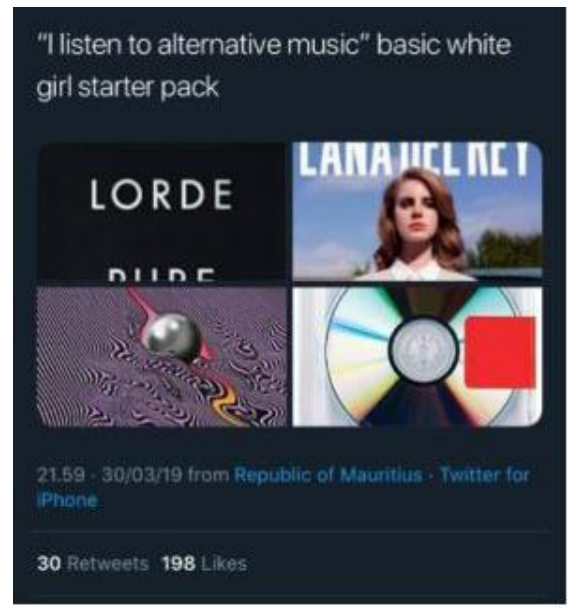

Picture 1

\begin{tabular}{ccc}
\hline Signs & Objects & Interpretant \\
\hline Lorde, Lana & Artists, Music & Lana Del Rey: \\
Del Rey, & Genre & American \\
Tame Impala, & & Singer, Lana \\
& & Del Rey: \\
& & Glamour, \\
\hline
\end{tabular}

Table 1. Data 1

The data are taken from the tweet above consists of 4 pictures. They are the album of Lorde, Lana Del Rey, and Tame Impala. Those pictures refer to the music taste of white girls in the US. Lana Del Rey is known as an American Singer who writes pop music. Her music describes the taste of white girls' music, which is identical to luxurious and seducing music. Somehow, the meaning that could be taken from this tweet is that most of white girls who listen to Lana Del Rey are rich white girls who have a similar taste in music.

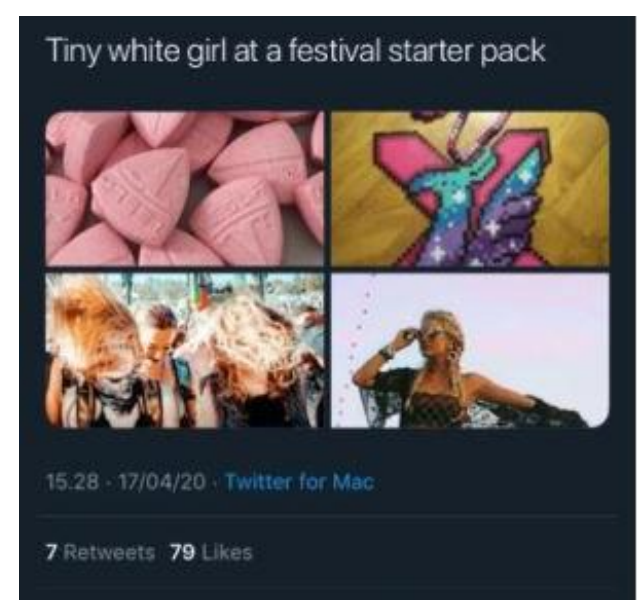

Picture 2

\begin{tabular}{ccc}
\hline Signs & Objects & Interpretant \\
\hline Tesla, Glitter & Economic & Tesla: white \\
Necklace, & status, Fashion & people \\
Blonde Hair, & style, Race, & economic \\
Music & Culture & status/rich \\
Festival & Background & people, \\
Outfit & & Blonde Hair: \\
& & white girls \\
& & genes,
\end{tabular}

\section{Table 2. Data 2}

The title of this \#starterpack tweet is "Tiny white girl at the festival." The data from the tweet above consists of 4 pictures: Tesla, glitter necklace, blonde hair, and music festival outfit. Those pictures refer to how the tiny white girls attend the US music festival. The music festival is usually staring well-known American artist. At the music festival, one ticket could cost millions. We cannot deny that the music festival is usually attended by white people, which means it could represent their Richie lifestyle. Most white people bring Tesla to the festival. Tesla is an American electric vehicle that could cost $\$ 39,990$. The meaning that could be taken from the objects above is how the US music festival could connect to the lifestyle of rich white people there.

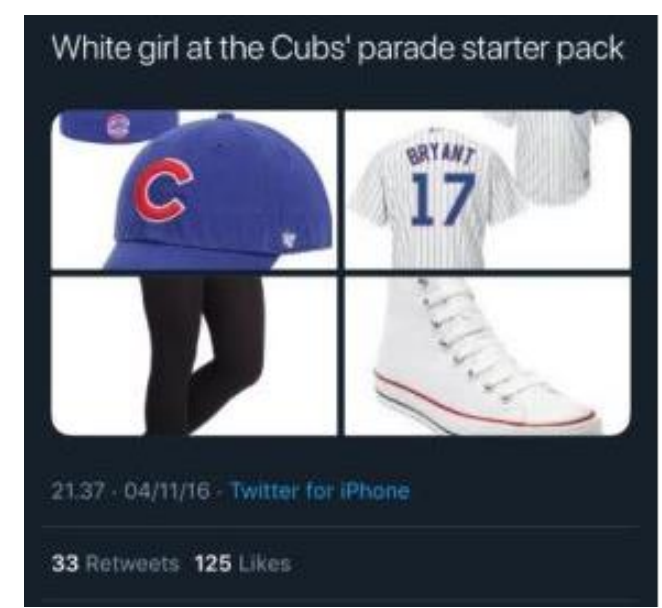

Picture 3

\begin{tabular}{ccc}
\hline Signs & Objects & Interpretant \\
\hline Baseball cap, & Fashion style, & Baseball cap \\
Baseball shirt, & culture. & and baseball \\
Leggings, & & shirt: baseball \\
Converse & & games event \\
sneakers. & & \\
\hline
\end{tabular}

Table 3. Data 3

The analyzed tweet consists of 4 pictures: a baseball cap, baseball shirt, leggings, and converse sneakers. Those pictures refer to how the girls crowd in the 
Cubs parade. Cubs World Series celebration is an event which gathers five million of human in one day in America. It is held in the US and attended by a lot of white girls. White girls always have the same style when they go to the Cubs Parade; baseball cap, baseball shirt, leggings, and converse shoes. Thus, the tweet's meaning above is how the Cubs parade could represent America's white girl's fashion style.

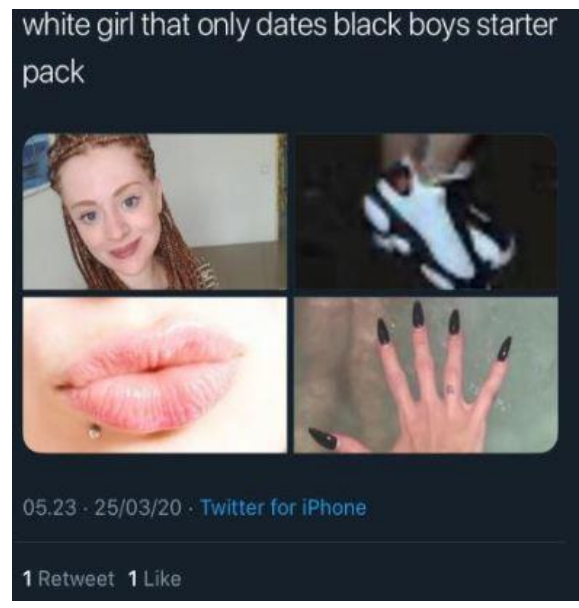

Picture 4

\begin{tabular}{ccc}
\hline Signs & Objects & Interpretant \\
\hline Corn-braid & & Corn braid \\
hair, high & Fashion & hair: Black \\
sneakers, & style, & people culture, \\
filler lips, & culture, & High sneakers, \\
acrylics nails & trend & and acrylics \\
& & nails: fashion \\
& & style \\
\hline
\end{tabular}

Table 4. Data 4

The user gave the tweet above "White girl that only dates black boys" as its title. White girls who crazy about black boys somehow always have the same style. They usually wear corn-braid hair in order to look like black girls. They also do some lips job to make their lips fuller. Lastly, most of them always wear high sneakers and acrylic nails to complete their style. Thus, we can recognize those kinds of girls just by seeing how the way they dressed.

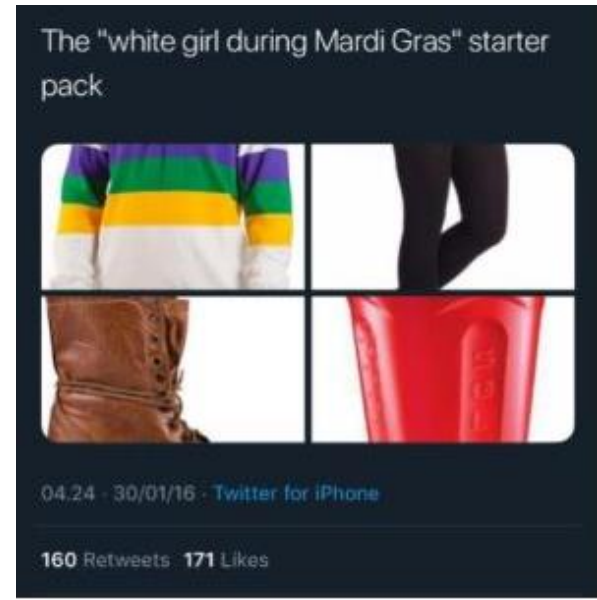

Picture 5

\begin{tabular}{ccc}
\hline Signs & Objects & Interpretant \\
\hline $\begin{array}{c}\text { Sweater, } \\
\text { leggings, }\end{array}$ & Fashion & Glass cup: \\
$\begin{array}{c}\text { Leather } \\
\text { boots, glass } \\
\text { cup. }\end{array}$ & & Drinking \\
habit/culture, & \\
& & \\
\hline
\end{tabular}

The \#starterpack tweet above is titled "White girl during Mardi Gras." The tweet contains four pictures. They are sweaters, leggings, leather boots, and a cup. Those pictures refer to the style that white girls in the Mardi gras used. Mardi Gras is a carnival celebration after the Christian feast. White girls who attend the Mardi Gras usually wear high boots, sweaters, and leggings.

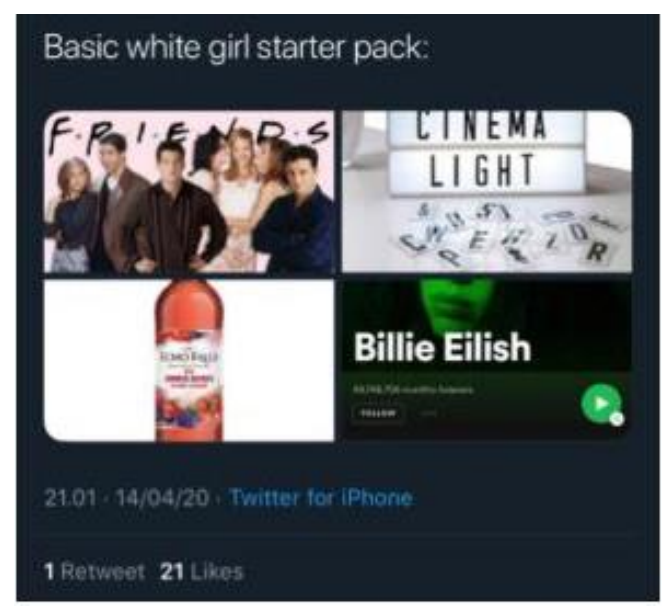

Picture 6 


\begin{tabular}{ccc}
\hline Signs & Objects & Interpretant \\
\hline Friends tv & Movie genre, & Alcohol \\
serial, & culture & beverages: \\
cinema, & background, & culture, Billie \\
alcoholic & music genre & Eilish: music \\
beverages, & & genre. \\
Billie Eilish & & \\
playlist & & \\
\hline
\end{tabular}

Tabel 6. Data 6

The data from the tweet above contain four pictures. They are Friends tv serial, alcohol beverages, and Billie Eilish playlist. White girls usually have the same taste in many things, including movies, music, and beverages. It is because the same circle usually shares the same taste. Meanwhile, Friends is a comedy tv serial that took place in New York. Friends represent the life of white people in common. That is why in conclusion, the tweet represents the life of white girls on an everyday basis.

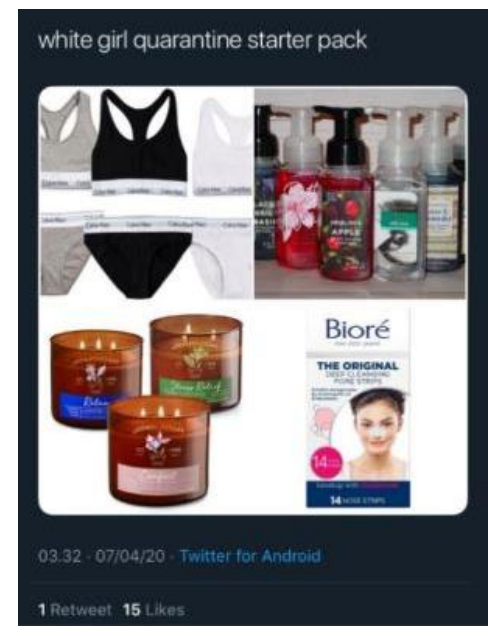

Picture 7

\begin{tabular}{ccc}
\hline Signs & Objects & Interpretant \\
\hline Calvin Klein & Brand & Clavin Klein, \\
underwear, & Loyalty, & Bath and \\
Bath and & economic & Body Works: \\
Bodyworks, & status & Luxury \\
Aromatheraphy & & Brand/Rich \\
candle, Biore & & people \\
pore pack. & & \\
\hline
\end{tabular}

Table 7. Data 7

The data above explain white girl's routine at home while quarantining. Clavin Klein underwear, Bath and Bodyworks products, aromatherapy candle, and Biore pore pack strongly connect with the white girls' quarantine routine. Most white girls enjoy their quarantine at home showered by high ended products. They wear Calvin Klein underwear at home, use bath and bodyworks products, and light some aromatherapy candles before they sleep. The pandemic does not affect white girls' economic status. They do not have to worry about how to find more cash in this pandemic season. They could stay at home and still enjoying their life peacefully.

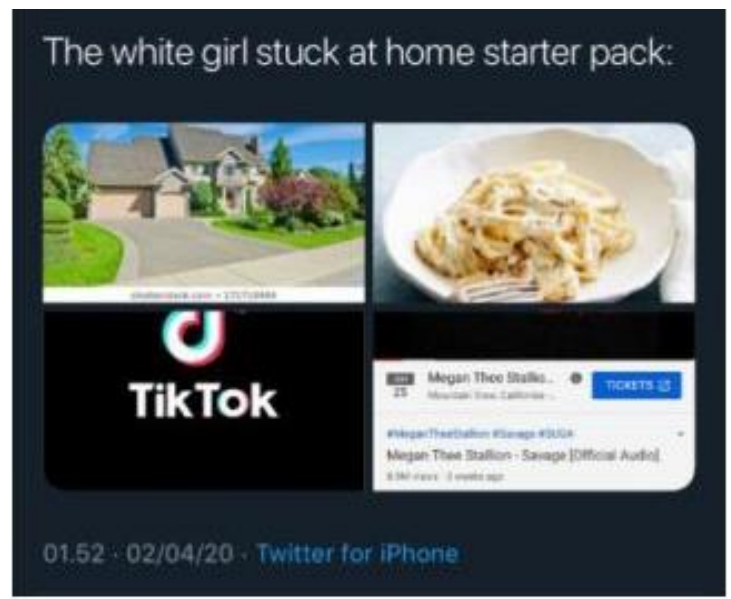

Picture 8

\begin{tabular}{ccc}
\hline Signs & Objects & Interpretant \\
\hline Big house, & Economic & Big house and \\
pasta & status, Trend & pasta: rich \\
cuisine, & & people, \\
TikTok & & TikTok and \\
app, Savage & & Savage by \\
by Megan & & Megan Thee \\
Thee & & Stallion: \\
Stallion & & Trend \\
\hline
\end{tabular}

Table 8. Data 8

Most white girls in the US spending their time at home now because of the COVID-19. From the data above, we could see that they usually live in luxurious blocks. They also spend their time cooking pasta. TikTok also becomes global trending in this global pandemic because of the number of users of this application increases during the pandemic. White girls in the US also spend most of their time playing the TikTok app. Last, because of TikTok, a new song by Megan Thee Stallion titled savage also becomes a global trending.

\section{CONCLUSION}

Based on the previous analysis, the researcher can summarize the gap seen in \#starterpack Tweets through the types of signs from Pierce's concept. The sign-in form of a representamen is something which stands to somebody or something in some capacity. 
It relates to objects addressed. The objects link to somebody or something created in a person's mind, an equivalent to the signs or more developed signs. The third part of the concept is interpretants creating a picture or mindset from the first and second signs or objects. Those concepts then lead to the various meaning that represents the life, style, and economy of white and black people. Then, those representations could lead to stereotyping.

\section{REFERENCES}

[1] Gronda, R. and Viola, T. (2016). Pragmatism and the writing of history. European Journal of Pragmatism and American Philosophy, Vol 8(2). http://journals.openedition.org/ejpap/611

[2] Duckitt, J. (2014). Prejudice: Its social psychology $\left(2^{\text {nd }} \mathrm{Ed}\right)$ by Ruppet Brown. Journal of Multilingual and Multicultural Development 35(2). https://www.researchgate.net/publication/2634 97849 Prejudice its social psychology

[3] Chandler, D. (2007). Semiotics the basics. New York: Routledge.

[4] Clair, M., \& Denis, J. S. (2015). Sociology of racism. International Encyclopedia of the Social and Behavioral Sciences 2 ${ }^{\text {nd }}$, Vol 9, p. 857-863. Elsevier Ltd.

https://scholar.harvard.edu/files/matthewclair/ files/clair denis 2015.pdf

[5] Cobley, P., \& Jansz, L. (1997). Introducing semiotics. New York: Totem Books. https://www.worldcat.org/title/introducingsemiotics/oclc/1035674505

[6] Culler, J. (2005). The pursuit of signs: Semiotics, literature, deconstruction. London: Routledge. http://atraf.ir/wpcontent/uploads/2018/10/jostojuyeneashaneha.pdf

[7] Deledalle, G. (2000). Charles S. Pierce's philosophy of signs. Bloomington, USA. Indiana University Press. https://isidore.co/calibre/get/pdf/5183

[8] Eco, Umberto. (1984). Semiotics and philosophy of language. Bloomington: Indiana University Press.
https://monoskop.org/images/b/b3/Eco Um berto Semiotics and the Philosophy of Lang uage 1986.pdf

[9] Jha, A. K., Raj, A., \& Gangwar, R. (2017). A Semiotic analysis of portraying gender in magazine advertisement. IOSR journal of Humanities and Social Sciences, Vol 22(5), p. 1-8. http://www.iosrjournals.org/iosrjhss/papers/Vol.\%2022\%20Issue5/Version11/A2205110108.pdf

[10]Kulaszewicz, K. E. (2015). Racism and the media: A textual analysis. Retrieved from Sophia, the St. Catherine University repository. https://www.coursehero.com/file/51279932/K ULASZECWIZ-2015pdf/

[11]Mc Garty, C., Yzerbyt, V. Y., \& Spears, R. (2002). Stereotypes as explanations: The formations of meaningful beliefs about social groups. Cambridge: Cambridge University Press.

https://perso.uclouvain.be/vincent.yzerbyt/Mc Garty $\% 20$ Yzerbyt $\% 20 \& \% 20$ Spears $\% 20$ MYS $\% 2$ 02002.pdf

[12] Yakin, H. S. M. \& Totu, A. (2014). The semiotic perspectives of Pierce and Saussure: A brief comparative study. Procedia: Social and Behavioral Sciences 155, p. 4-8. http://repo.uum.edu.my/12976/1/1-s2.0.pdf

[13]Da Silva, D. (2019). Semiotics. New World Encyclopedia. Retrieved at January 1, 2020 from

https://www.newworldencyclopedia.org/p/inde x.php?title $=$ Semiotics\&oldid $=1026594$

[14]Tyree, T. C. M., Byerly, C. M., \& Hamilton, K. A. (2011). Representations of (new) Black masculinity: A news-making case study. Journalism Vol 13(4), p. 467-482.

https://doi.org/10.1177/1464884911421695

[15]Rattansi, A. (2007). Racism a very short introduction. Oxford: Oxford University Press. https://doi.org/10.1093/actrade/978019280590 $\underline{4.001 .0001}$ 
[16]Quinn, K. A., Macrae, C. N., \& Bodenhausen, G. V. (2007). Stereotyping and impression formation: How categorical thinking shapes person perception. London: SAGE Publication. https://www.researchgate.net/publication/2929 32601 Stereotyping and impression formation How categorical thinking shapes person per ception 